Article

\title{
Immobilization Effects on the Catalytic Properties of Two Fusarium Verticillioides Lipases: Stability, Hydrolysis, Transesterification and Enantioselectivity Improvement
}

\author{
Fernanda Dell Antonio Facchini ${ }^{1}$, Marita Gimenez Pereira ${ }^{2}$, Ana Claudia Vici ${ }^{2}$, Marco Filice ${ }^{3}$, \\ Benevides Costa Pessela ${ }^{4}$, Jose Manuel Guisan ${ }^{5}$ (D), Glória Fernandez-Lorente ${ }^{4}$ and \\ Maria de Lourdes Teixeira de Moraes Polizeli ${ }^{2, * \text { (D) }}$ \\ 1 Departamento de Medicina, Faculdade de Medicina de Ribeirão Preto, Universidade de São Paulo, \\ 14040-900 Sao Paulo, Brazil; fda.facchini@gmail.com \\ 2 Departamento de Biologia, Faculdade de Filosofia, Ciências e Letras de Ribeirão Preto, \\ Universidade de São Paulo, 14040-901 Sao Paulo, Brazil; maritagimenez@hotmail.com (M.G.P.); \\ acvici@gmail.com (A.C.V.); polizeli@ffclrp.usp.br (M.L.T.M.P.) \\ 3 Nanobiotechnology, Molecular Imaging and Metabolomics Group, \\ Spanish National Centre for Cardiovascular Research-CNIC, 28029 Madrid, Spain; \\ marco.filice1@gmail.com \\ 4 Departamento de Biotecnología y Microbiologia de los Alimentos, Instituto de Ciencias de la Alimentación, \\ CIAL-CSIC, Calle Nicolás Cabrera 9, CampusUAM, 28049 Cantoblanco, Spain; b.pessela@csic.es (B.C.P.); \\ gflorente@ifi.csic.es (G.F.-L.) \\ 5 Departamento de Biocatálisis, Instituto de Catálisis y Petroleoquímica-CSIC, Campus UAM, Cantoblanco, \\ 28049 Madrid, Spain; jmguisan@icp.csic.es \\ * Correspondence: polizeli@ffclrp.usp.br; Tel.: +55-16-3602-4680; Fax: +55-16-3602-4886
}

Received: 15 December 2017; Accepted: 2 February 2018; Published: 16 February 2018

\begin{abstract}
Fusarium verticillioides lipases were purified in a "cascade" method using octadecyl Sepabeads and octyl Sepharose resins, which led to the isolation of two proteins with lipolytic activities. Lip 1 was purified after octyl Sepharose adsorption presenting $30.3 \mathrm{kDa}$ and, Lip 2 presented $68.0 \mathrm{kDa}$ after octadecyl adsorption. These immobilization processes resulted in an increase of 3-fold in activity of each immobilized enzyme. These enzymes presented optima of $\mathrm{pH}$ of 5.0 and 6.0, respectively and temperature at $40^{\circ} \mathrm{C}$. They were thermostable at $40^{\circ} \mathrm{C}$ and both remained more than $50 \%$ of its activity at the $\mathrm{pH}$ range of 5.0 to 7.0 , with $180 \mathrm{~min}$ of incubation. The sardine oil hydrolysis showed higher EPA/DHA ratio. Concerning the ethanolysis reaction, Lip 2 showed higher conversion (5.5\%) and both lipases showed activity in the release of the $\mathrm{S}$ enantiomers from 2-O-butyryl-2-phenylacetic acid (mandelic butyrate acid) and HPBE hydrolysis. Lip 2 also demonstrated capacity of transesterification. These applications made these enzymes attractive for industrial application.
\end{abstract}

Keywords: immobilization; purification; lipase; Fusarium verticillioides; EPA; DHA

\section{Introduction}

Lipases are very interesting enzymes due to their ability to catalyze a wide range of reactions, such as synthesis, transesterification and ester hydrolysis in aqueous or organic media, accompanied with a high regio- or enantioselectivity. The interest in this class of enzymes essentially increased due to their industrial and biotechnological applications in oil and fat hydrolysis and also because of their capacity to recognize different synthetic or natural substrates. Additionally, the increasing interest in the kinetic resolution of racemic mixtures with high regio- and stereo-specificities producing intermediates for 
pharmaceutical industries as well as the use of fatty acid esters synthesis as cosmetic ingredients or surfactants, pesticides and agro-chemistry synthesis are also interesting [1-5]. Currently, due to these broad uses, they are attractive in biotechnological application and there is an increasing search for new microorganisms able to produce these enzymes with different specificities and stabilities.

Aiming their biotechnological applications, lipases should be stable enough to be reused for several reaction cycles. Consequently, immobilization techniques can improve this stability and catalytic properties leading to higher catalyst efficiencies [3,6-9]. Another advantage is the enzyme purification which minimizes or eliminates the contamination of other proteins, as shown in this work. Lipase adsorption on a cascade of hydrophobic supports at low ionic strength is a new purification strategy, capable to separate two or more enzymes with different hydrophobicity at low cost, fast procedure and high yield $[1,10]$.

The selectivity of these enzymes is another attractive feature that enables their use in a large number of applications, which includes the resolution of racemic mixtures. Consequently, the enantioselectivity is gaining more and more space in industrial processes and in fine chemistry biocatalysts due to its importance in the preparation of pure enantiomers of chiral intermediates, which have been widely applied in synthetic purposes as well as stereochemical investigations. $[4,11-13]$.

Besides, the use of lipases on fish oil reactions has increased in the last years. The release of omega-3 fatty acids [e.g. eicosapentaenoic acid (EPA) and decosahexaenoic acid (DHA)] from this oil have encouraged many studies involving health and food professionals, once these acids are able to improve the learning ability, mental development and visual perception in the early stages of life as well as prevent cardiovascular diseases in adults [3,14].

Fusarium verticillioides is among the most common Fusarium spp. infecting maize in most areas of the world and they are also famous in the production of fumonisin. Fusarium sp. has recently been described as a remarkable lipase producer [15-17], however no publication was found describing lipases from Fusarium verticillioides.

In this context, this study aims a high selective purification of two lipases from Fusarium verticillioides by their immobilization in hydrophobic supports, in which the stability of lipases was increased and the catalytic properties were improved through modulation of the enzyme properties with immobilization procedures.

\section{Results and Discussion}

\subsection{Hydrophobic Immobilization}

It was important to test the behavior of $F$. verticillioides crude extract on different supports with increasing levels of hydrophobicity. The crude extract containing lipases was adsorbed on all supports tested at different adsorption rates (Table 1). Except by Butyl Sepharose, lipases were efficiently immobilized in all the other supports, which showed more than $100 \%$ of residual activity presenting an activation above 2-fold. Phenyl Toyopearl derivative was the one with the highest activation, despite having only $50 \%$ immobilization. Other lipases of fungi described in the literature also presented activation when immobilized $[1,18,19]$.

Table 1. Lipase immobilization on hydrophobic supports at $\mathrm{pH}$ 7.0.

\begin{tabular}{ccc}
\hline Derivatives & Immobilization (\%) & Fold * \\
\hline Butyl Sepharose & $28.2 \pm 2.0$ & 0.1 \\
Phenyl Toyopearl & $50.0 \pm 2.0$ & 3.7 \\
Hexyl Toyopearl & $59.6 \pm 0.8$ & 2.6 \\
Octyl Sepharose & $74.3 \pm 1.0$ & 2.4 \\
Octadecyl Sepabeads & $89.3 \pm 0.5$ & 2.6 \\
\hline
\end{tabular}
$*$ Fold-degree of activation and/or inhibition of the lipases when immobilized on hydrophobic supports, compared
to their free form. 
The phenomenon of hyper-activation could occur possibly due to the fact that when lipases are immobilized on hydrophobic supports, they keep the lid open, exposing the active site, which facilitates substrate input resulting in an easier hydrolysis [20].

\subsection{Cascade Purification of Two Lipases}

Possibly, in the enzymatic crude extracts, more than one type of lipase could be present and in order to verify this possibility in F. verticillioides crude extract, a SDS-PAGE analysis was performed. Notably, the presence of two lipases were suggested: one totally adsorbed octyl derivative and the other adsorbed in octadecyl derivative.

In order to separate these possible lipase isoforms from this crude extract a cascade purification strategy using two hydrophobic supports was performed. Initially, $70 \%$ of the active lipase (confirmed by $p$ NPB assay) was adsorbed on octyl Sepharose (Lip1) after $3 \mathrm{~h}$ (Supplementary Figure S1A) and the supernatant containing the remaining lipase activity (Lip2) was further incorporated to octadecyl Sepabeads, which resulted in a total lipase adsorption (Supplementary Figure S1B). No lipase activity was observed in the supernatant after octadecyl immobilization. A single band in each support corresponding to Lip1 and Lip2 could be observed by this cascade technique. Afterwards, both pure lipases were fully desorbed from each support by incubating $1 \mathrm{~g}$ of the derivatives with $10 \mathrm{~mL}$ crescent Triton X-100 solution $(1 \%, v / v)$ (Figure 1). At $0.3 \%$ Triton-X100 was sufficient to desorb $100 \%$ of Lip1 and the same concentration desorbed 80\% of Lip2. Purified Lip1 and Lip2 presented 30.3 and $68 \mathrm{kDa}$, respectively. Table 2 summarizes the purification steps of the lipases from F. verticillioides. The immobilization on Octyl provided a purification factor of 2.14 -fold with $44.5 \%$ protein recovery and the immobilization on octadecyl resulted in a purification factor of 4.1 -fold and $25.7 \%$ protein recovery. The total recuperation was $70.2 \%$.

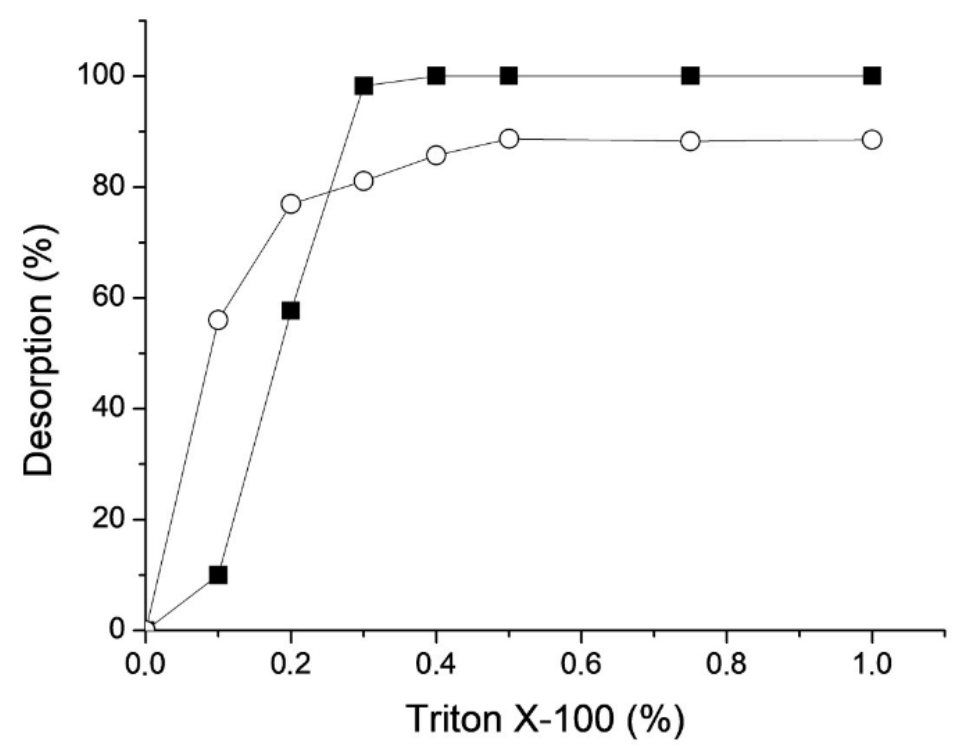

Figure 1. Desorption of the immobilized lipases on octyl and octadecyl supports. Full squares: octyl derivatives (Lip1); empty circles: octadecyl derivatives (Lip2).

Table 2. Purification of two lipases from F. verticillioides.

\begin{tabular}{cccccccc}
\hline Enzyme & $\begin{array}{c}\text { Volume } \\
(\mathbf{m L})\end{array}$ & Mass (g) & $\begin{array}{c}\text { Total } \\
\text { Activity (U) }\end{array}$ & Immobilization (\%) & $\begin{array}{c}\text { SA } \\
(\mathbf{U} / \mathbf{m g})\end{array}$ & $\begin{array}{c}\text { Recuperation } \\
\mathbf{( \% )}\end{array}$ & $\mathbf{P F}^{* *}$ \\
\hline Crude extract & 10 & - & 21.8 & - & 90.8 & 100 & 1 \\
Octyl & - & 1.0 & 9.7 & 70 & 194.0 & 44.5 & 2.14 \\
Octadecyl & - & 1.0 & 5.6 & $100^{\mathrm{a}}$ & 373.3 & 25.7 & 4.11 \\
\hline
\end{tabular}

${ }^{*} \mathrm{SA}=$ specific activity; ** $\mathrm{PF}=$ purification factor $\left(\mathrm{SA} / \mathrm{SA}_{\text {crude extract }}\right)$; ${ }^{a}$ lipase immobilized from octyl supernatant. 


\subsection{Thermal Stability of Derivatives}

After the cascade purification, both lipases were desorbed from the supports where they were previously immobilized. Further, both lipases were immobilized on CNBr-activated supports (Table 3). FVL1 exhibited 53.5\% of immobilization while FVL2 presented 38.3\%. The uni-punctual immobilization on $\mathrm{CNBr}$ support was used as control in the characterization experiments, because, as this linkage does not modify the enzyme characteristics, this type of immobilization simulates the activity of the enzyme in its free form.

Table 3. F. verticillioides lipases immobilization at uni-punctual support.

\begin{tabular}{ccc}
\hline Lipase & Time (min) & Immobilization (\%) \\
\hline FVL1 & 30 & 53.5 \\
FVL2 & 30 & 38.3 \\
\hline
\end{tabular}

Therefore, lipase thermal stability of soluble and immobilized lipase on different supports was compared at $40^{\circ} \mathrm{C}$ and $50^{\circ} \mathrm{C}$. At $50^{\circ} \mathrm{C}$, after $24 \mathrm{~h}$, all derivatives presented residual activity of less than $40 \%$ (Figure 2). This may have occurred because, at these temperatures, the enzyme could possibly be desorbed and may have aggregated, reducing the stability. At $40{ }^{\circ} \mathrm{C}$, in $24 \mathrm{~h}$, the uni-punctual immobilized Lip1 and Lip2 on CNBr lost about $35 \%$ and $85 \%$ of their residual activities, respectively. Therefore, at this temperature, the immobilization on octyl Sepharose and octadecyl Sepabeads supports contributed to increase Lip1 and Lip2 stabilities when compared to the CNBr-activated supports, thereby extending their application range.

A

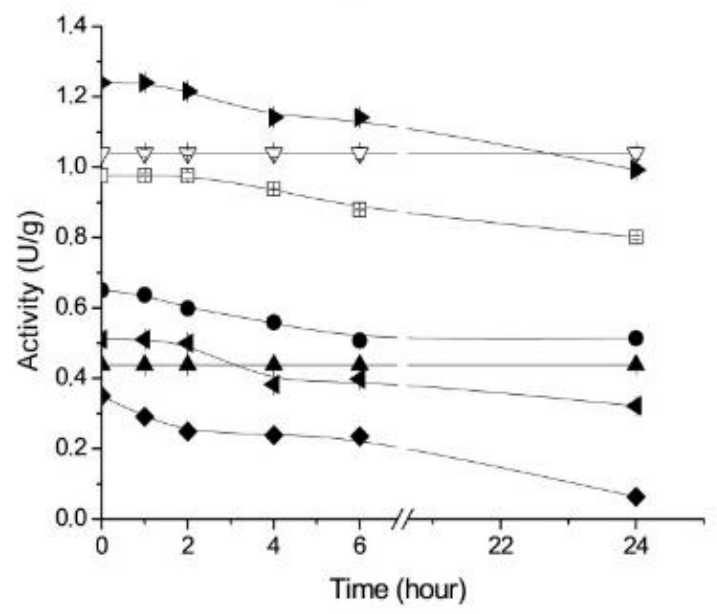

B

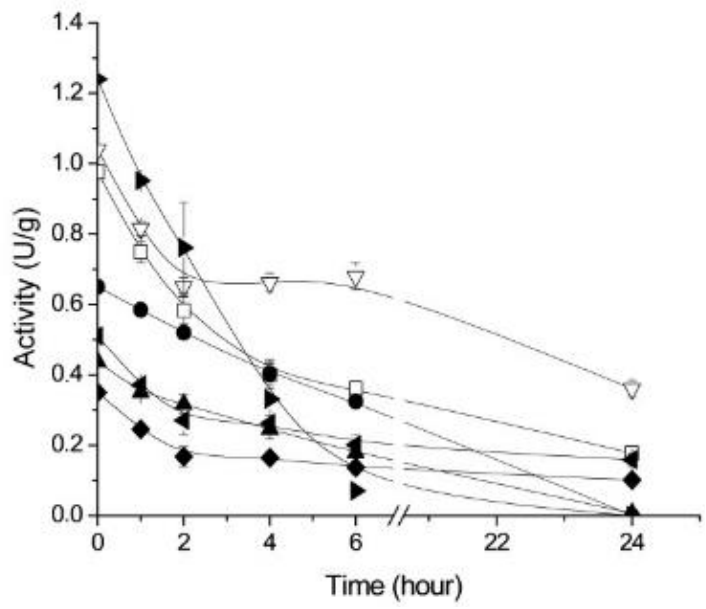

Figure 2. Thermal stability of F. verticillioides lipases (A) $40{ }^{\circ} \mathrm{C}$ (B) $50{ }^{\circ} \mathrm{C}$. Symbols: $-\square$ - Butyl Sepharose; -- Hexyl Toyopearl; - $\mathbf{\Delta}$ - Phenyl Toyopearl; - $\nabla$ - Octyl Sepharose; - - -Octadecyl Sepabeads - - CNBr-activated Lip1 and - - CNBr-activated Lip2.

Increased thermal stability of derivatives was also observed by Cunha et al. the stability of butyl and octyl derivatives increased as the $\mathrm{pH}$ decreased, at $30^{\circ} \mathrm{C}$, retaining $78 \%$ to $100 \%$ of the lipolytic activity after $48 \mathrm{~h}$ [1]. Lipase from Thermomyces lanuginosa presented a more stable derivative obtained from hexyl Toyopearl than the others studied, whereas octyl agarose showed an intermediate stability [21]. 


\subsection{Biochemical Characterization of Purified and Free Lipases}

\subsection{1. $\mathrm{pH}$ and Temperature Effects}

The optimum $\mathrm{pH}$ values obtained for both free lipases showed a slightly acidic character (Figure 3A). The optima pH observed were 6.0 and 5.5, respectively to Lip1 and Lip2. The optimum temperature for both lipases studied was $40{ }^{\circ} \mathrm{C}$; however, Lip1 presented activity higher than $50 \%$ in a range of $25{ }^{\circ} \mathrm{C}$ to $55^{\circ} \mathrm{C}$ (Figure $3 \mathrm{~B}$ ). The same optimum temperature was observed to Pseudomonas monteilii [22] and the optimum $\mathrm{pH}$ of 8.0.
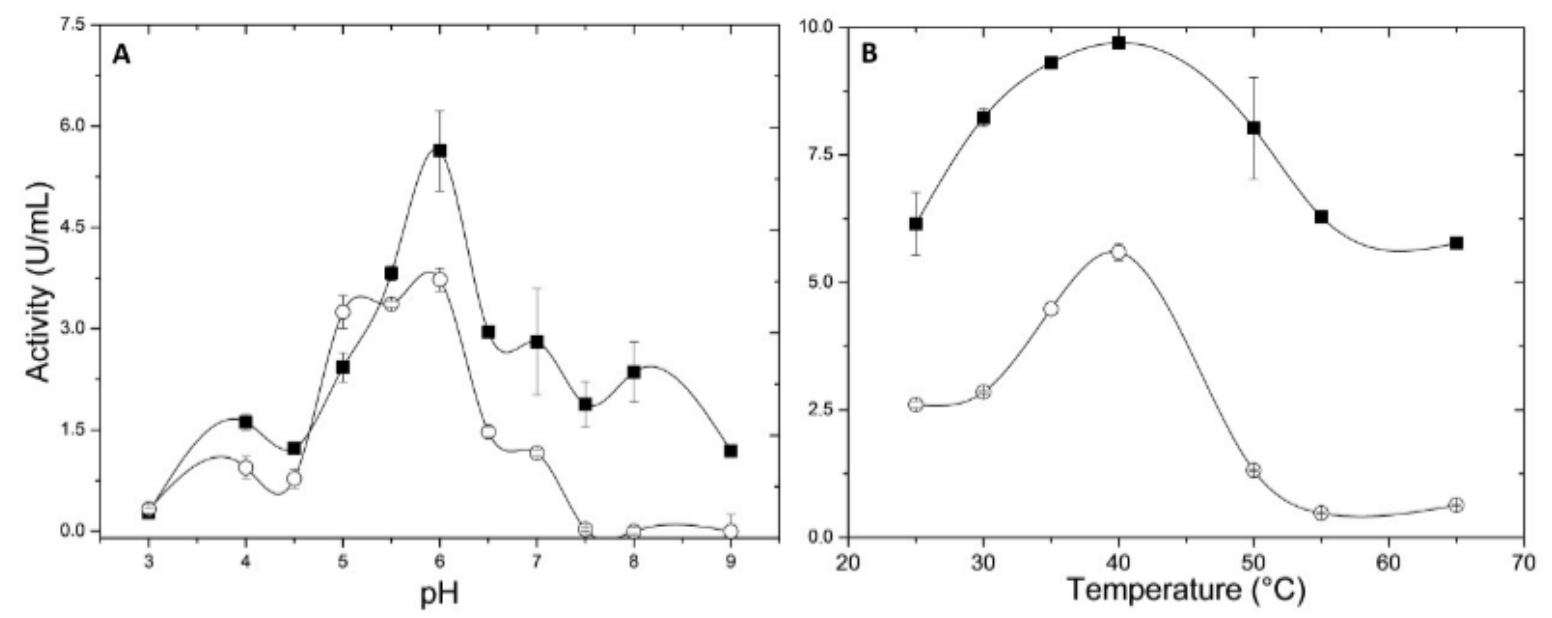

Figure 3. Fusarium verticillioides free lipases characterization. (A) $\mathrm{pH}$ effect in enzymatic activity; (B) temperature effect in enzymatic activity. Symbols: - $\mathbf{-}$ - Lip1;-○- Lip2.

Regarding $\mathrm{pH}$ stabilities (Figure 4), both lipases maintained more than $50 \%$ of their residual activity in a $\mathrm{pH}$ range of 5.0-7.0, with $180 \mathrm{~min}$. Lip 1 presented better $\mathrm{pH}$ stability than Lip 2, at non-suitable $\mathrm{pH}(4,5,9$ and 10$)$ maintaining at least $20 \%$ of its activity. Concerning the thermal stability, Lip1 also presented better stability than Lip2 at temperatures of 40,50 and $60{ }^{\circ} \mathrm{C}$ (Figure 5A). Both lipases are $60 \%$ stable at $30{ }^{\circ} \mathrm{C}$ with $180 \mathrm{~min}$.

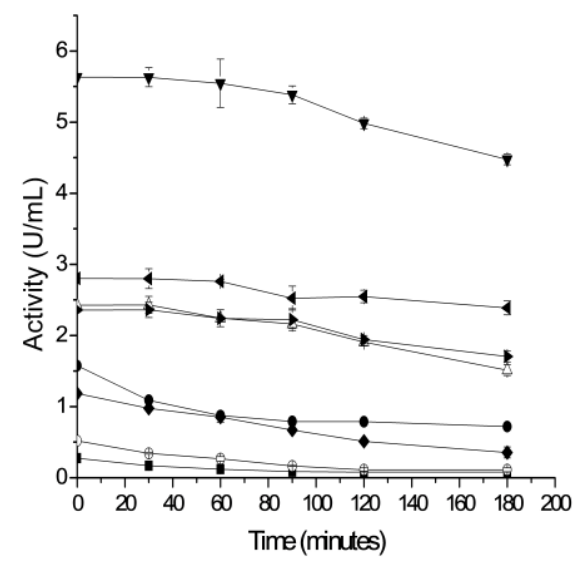

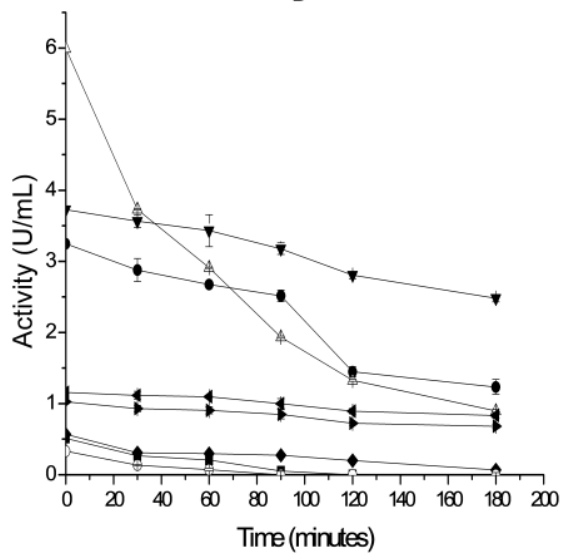

Figure 4. pH stability of pure lipases (A) Lip1 (B) Lip2. pH symbols: - $\mathbf{\square}-3.0 ;-\mathbf{-}-4.0 ;-\triangle-5.0 ;-\boldsymbol{\nabla}-6.0$; $-4.0 ; \rightarrow-8.0 ;->-9.0 ;-\bigcirc-10.0$. 

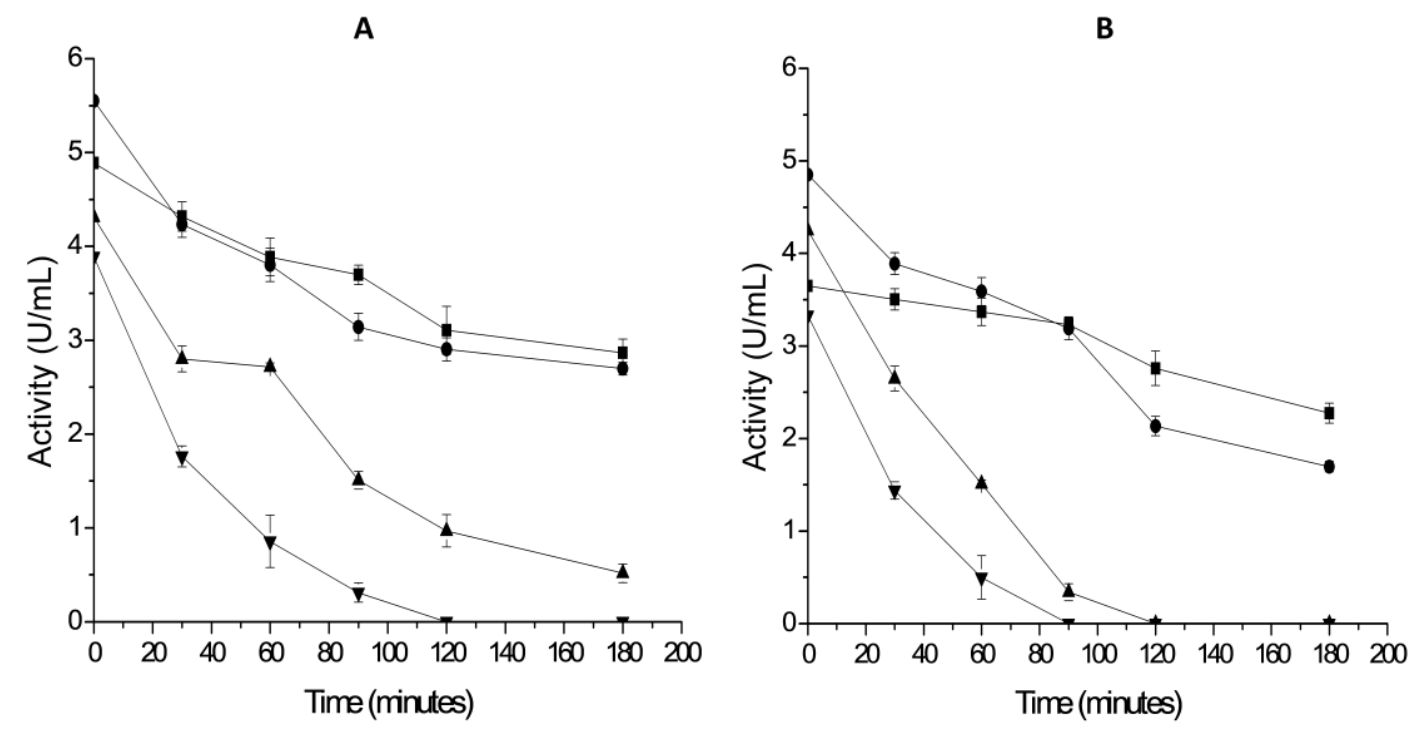

Figure 5. Thermal stability of pure lipases (A) Lip1 (B) Lip2. pH symbols: $50{ }^{\circ} \mathrm{C} ;-\boldsymbol{\nabla}-60^{\circ} \mathrm{C}$.

Generally, free lipases from mesophilic fungi are active and stable at temperatures between 25 and $40{ }^{\circ} \mathrm{C}$ [23]. F. solani lipase was stable up to $45^{\circ} \mathrm{C}$ and in a range of $\mathrm{pH} 5-10$. Above this temperature, the stability decreased [15]. The lipase obtained from Aspergillus niger was stable at $40^{\circ} \mathrm{C}$ for $3 \mathrm{~h}$ but it sharply decreased when the temperature was increased, losing $52 \%$ of its original activity at $50{ }^{\circ} \mathrm{C}$ after $1 \mathrm{~h}$. However, in alkaline $\mathrm{pH}$, the residual activity remained $100 \%$ after $24 \mathrm{~h} \mathrm{[24].}$

\subsubsection{Effect of Metallic Ions}

In this experiment, $\mathrm{Ca}^{2+}$ and $\mathrm{Ba}^{2+}$ ions increased the activity of both lipases (Figure 6). Barium had a better effect on Lip1, increasing activity by $20 \%$ and $60 \%$ using the final concentrations of $5 \mathrm{mM}$ and $10 \mathrm{mM}$, respectively. However, $\mathrm{Ba}^{2+}$ decreased Lip2 activity by $30 \%$ when $5 \mathrm{mM}$ of this ion was used. On the other hand, $\mathrm{Ba}^{2+}$ increased the activity of the same enzyme by $45 \%$ when $10 \mathrm{mM}$ (final concentration) was added. Calcium had no effect on Lip1 at the final concentration of $5 \mathrm{mM}$ but at $10 \mathrm{mM} \mathrm{Ca}^{2+}$ was able to activate the enzyme in $20 \%$. In contrast, $\mathrm{Ca}^{2+}$ activated Lip 2 in about $45 \%$ in both concentrations. Calcium activation corroborates with literature results, since it is well-known that some lipases described are positively influenced by this ion, for the reason that in a calcium-free system, lipases are not able to adsorb at the water-fat interface and no lipolytic activity occurs $[22,25,26]$. On the other hand, it is known that heavy metals inhibit lipase activity as copper, aluminum and zinc ions. Consequently, in this study $\mathrm{Co}^{2+} \mathrm{Al}^{3+}$ and $\mathrm{Cu}^{2+}$ ions and EDTA decreased Lip1 activity around $40 \%$ and $\mathrm{Pb}^{+}$and $\mathrm{Zn}^{2+}$ decreased approximately $60 \%$ Lip2 activity, while other ions did not affect them significantly. The inhibition by $\mathrm{Zn}^{2+}$ and $\mathrm{Hg}^{2+}$ ions was observed for the lipase from Mortierela alliacea [26]. 
A

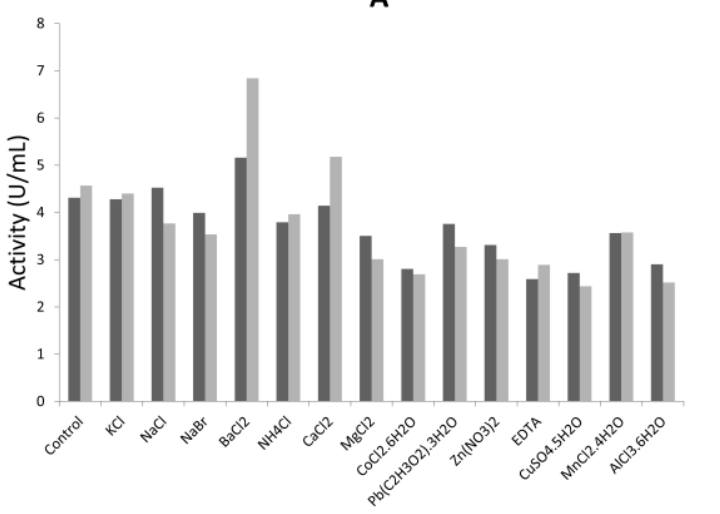

B

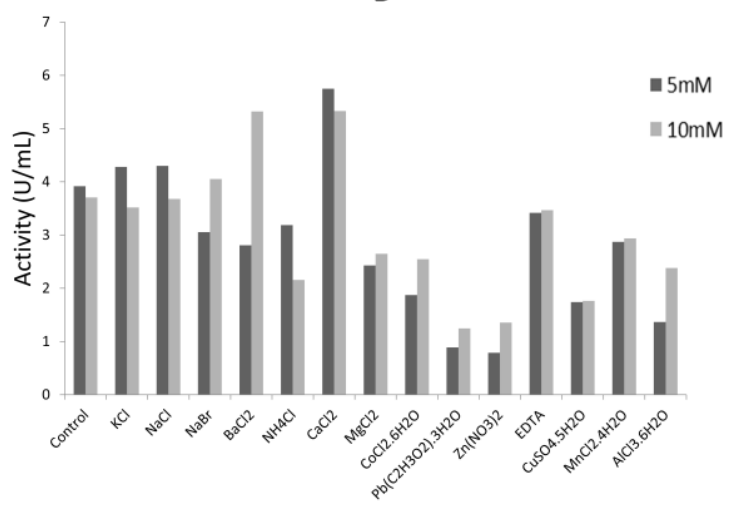

Figure 6. Effect of ions on lipases activity (A) Lip1 e (B) Lip2.

\subsubsection{Isoelectric Point and Kinetic Parameters}

The kinetic parameters of $F$. verticillioides purified lipases were calculated using $p$-nitrophenylpalmitate synthetic substrate (pNPP). The purified lipases had their kinetic parameters $\left(\mathrm{K}_{\mathrm{M}}\right.$ and $\mathrm{V}_{\max }$ ) calculated by SigrafW software and they were described in Table 4 . The value of $\mathrm{K}_{\mathrm{M}}$ and $V_{\max }$ obtained for Lip1 were $0.16 \mathrm{mM}$ and $47.71 \mathrm{U} / \mathrm{mg}$ protein, respectively $(n=1.78)$. Lip2 $\mathrm{K}_{\mathrm{M}}$ and $\mathrm{V}_{\max }$ values were $0.26 \mathrm{mM}$ and $37.4 \mathrm{U} / \mathrm{mg}$, respectively. The values of the isoelectric points for Lip1 were 5.2 and for Lip 2 were around 4.2-5.0.

Table 4. Kinetic parameters of F. verticillioides purified lipases

\begin{tabular}{|c|c|c|c|c|}
\hline Enzyme & $\mathrm{K}_{\mathrm{M}}(\mathrm{mM})$ & $\begin{array}{c}\mathrm{V}_{\max } \\
\left(\mathrm{U} \cdot \mathrm{mg} \cdot \text { protein }^{-1}\right)\end{array}$ & kcat $\left(s^{-1}\right)$ & $\begin{array}{c}\mathrm{kcat} / \mathrm{K}_{\mathrm{M}} \\
\left(\mathrm{M}^{-1} \cdot \mathrm{s}^{-1}\right)\end{array}$ \\
\hline Lip1 & 0.16 & 47.71 & $2.00 \times 10^{9}$ & $1.25 \times 10^{13}$ \\
\hline Lip2 & 0.26 & 37.4 & $3.53 \times 10^{9}$ & $1.35 \times 10^{13}$ \\
\hline
\end{tabular}

Lipase from Aspergillus fumigatus presented $\mathrm{K}_{\mathrm{M}}$ of $14 \mathrm{mM}$ and $\mathrm{V}_{\max }$ of $1.37 \mathrm{mM} \cdot \mathrm{mg}^{-1} \cdot \mathrm{min}^{-1}$ with $p$-nitrophenyl acetate [27]; even lower values were found to Aspergillus japonicus lipase, for which $\mathrm{K}_{\mathrm{M}}$ and $\mathrm{V}_{\max }$ were $0.64 \times 10^{-3} \mathrm{mmol}$ and $0.25 \mu \mathrm{mol} \cdot \mathrm{min}^{-1} \cdot \mathrm{mL}^{-1}$ [28]. Vici et al. [29] obtained from a recombinant lipase from Beauveria bassiana a $\mathrm{K}_{\mathrm{M}}$ and $\mathrm{V}_{\max }$ value of $0.5546 \mu \mathrm{M}$ and $85.67 \mu \mathrm{mol} \cdot \mathrm{min}^{-1} \cdot \mathrm{mg}^{-1}$ respectively, against $p \mathrm{NPB}, \mathrm{pH} 6.0$ at $50^{\circ} \mathrm{C}$.

\subsection{Lip1 and Lip 2 Biotechnological Applications}

\subsubsection{Transesterification Reaction Applications}

Both purified lipases adsorbed on octadecyl supports were submitted to this transesterification reaction. A control sample was performed using the same assay conditions without enzyme to each oil tested (Figure 7). Ethanol was used in all reactions. 


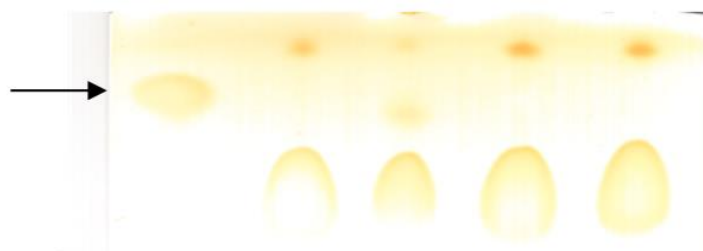

A

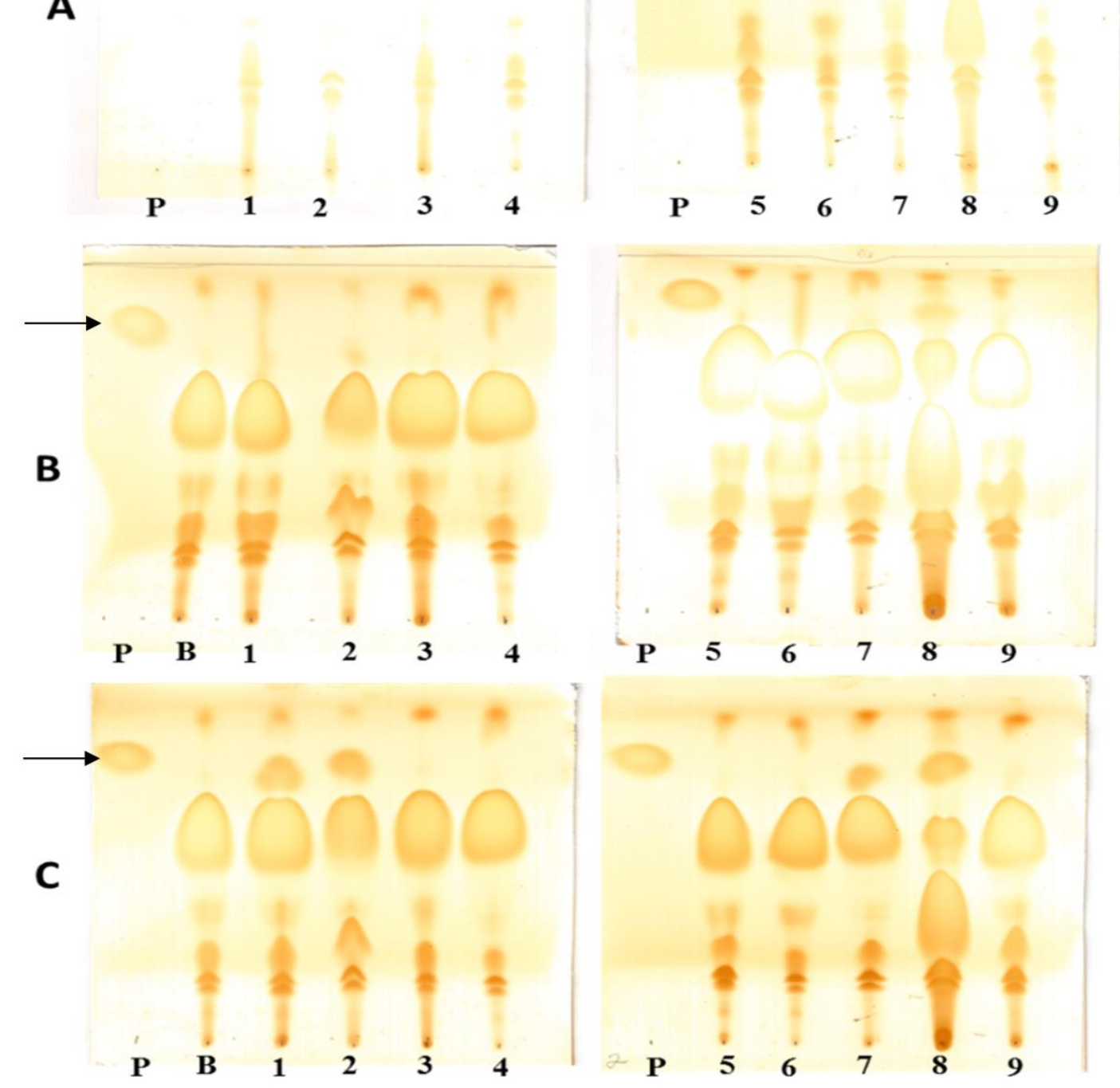

Figure 7. Transesterification assay with ethanol in different oils (black arrow). (A) Control (B) Lip1 adsorbed in octadecyl (C) Lip2 adsorbed on octadecyl. P = ethyl oleate $1 \%, \mathrm{~B}=$ soy oil control, 1 = soy oil, 2 = macaúba almond oil, 3 = canola oil, $4=$ corn oil, 5 = pequi oil, $6=$ sunflower oil, 7 = olive oil, 8 = macaúba pulp oil, 9 = sesame oil.

Macaúba pulp oil and macaúba almond oil controls presented bands which corresponded to the expected ethyl ester, possibly due to the presence of free fatty acids in these oils. However, the derivatives were able to react and release ester (Figure 7). Lip1 showed lower ability than Lip2, which showed a notable transesterification capacity with soybean oil, almond and macaúba pulp as well as olive oil, producing esters. It could make these enzymes attractive for industrial and biodiesel applications.

The conversion rate of the transesterification reaction was also checked by gas chromatography coupled to a mass spectrometer (Table 5). The highest conversion was observed on macaúba pulp, about $4 \%$. Several authors studied the immobilization of lipases from different sources in biodiesel production [30-32]. 
Table 5. Conversion rate of the transesterification reaction to Lip2 derivative.

\begin{tabular}{ccc}
\hline Samples & Oils & Conversion (\%) \\
\hline Ethyl oleate 1\% & & 100 \\
\hline \multirow{2}{*}{ Controls } & Soy oil & 0.0 \\
& Macaúba pulp oil & 0.29 \\
& Macaúba almond oil & 0.13 \\
& Olive oil & 0.0 \\
\hline \multirow{3}{*}{ Octadecyl Sepabeads (Lip2) } & Soy oil & 1.71 \\
& Macaúba pulp oil & 3.62 \\
& Macaúba almond oil & 1.28 \\
& Olive oil & 1.18 \\
\hline
\end{tabular}

\subsubsection{Ethanolysis of Sardine Oil}

Both free and pure lipases were first adsorbed on octadecyl supports in order to be used in ethanolysis reaction and presented activities around $0.3-0.5 \mathrm{U} / \mathrm{mL}$. Lip2 derivatives presented a conversion rate about 2-fold higher than Lip1 (Table 6). This result was significant to demonstrate the ability to synthesize esters from oils (important feature for biodiesel production). However, it was lower when compared to the selectivity of commercial lipase from Thermomuyces lanuginosus, Candida albicans B and Rhizomucor miehei (Novo Nordish, Denmark) [33].

Table 6. Ethanolysis of sardine oil catalyzed by F. verticillioides lipases adsorbed to octadecyl Sepabeads in cyclohexane.

\begin{tabular}{cccc}
\hline Derivative & Ester & Conversion (\%) & Selectivity (EPA/DHA) \\
\hline \multirow{2}{*}{ Control } & EPA & nd ${ }^{*}$ & nd $^{*}$ \\
& DHA & nd & \multirow{2}{*}{1.25} \\
\hline \multirow{2}{*}{ Lip1 } & EPA & 2.1 & 1.15 \\
& DHA & 1.7 & \multirow{2}{*}{ Lip2 } \\
\multirow{2}{*}{ EPA } & 5.5 &
\end{tabular}

\subsubsection{Sardine Oil Hydrolysis}

The main purpose of this experiment was to examine the specificity of lipases by EPA/DHA ratio, as well as check the lipases behavior on hydrolysis reaction, to confirm the enzyme activity as lipases. Both lipases could hydrolyze the sardine oil. Lip1 immobilized on octyl Sepharose support, presented the best conversion (6\% EPA and 2.4\% DHA) and a great ratio between both omega 3 released, EPA/DHA 14.72 (Table 7). Lip2 presented a better conversion rate in EPA. Results published by Pereira et al. [20] showed a ratio of 3.0 with glyoxyl-immobilized lipase from Trichoderma pseudokoningii.

Table 7. Sardine oil hydrolysis catalyzed by F. verticillioides lipase immobilized on hydrophobic support.

\begin{tabular}{cccccc}
\hline \multirow{2}{*}{ Enzyme } & Derivative & $\begin{array}{c}\text { Selectivity } \\
\text { (EPA/DHA) }\end{array}$ & EPA (\%) & DHA (\%) & $\begin{array}{c}\text { Total } \\
\text { Conversion (\%) }\end{array}$ \\
\hline \multirow{2}{*}{ Lip1 } & Octyl & 14.72 & 6.00 & 2.40 & 8.40 \\
& CNBr-activated & 19.57 & 1.50 & 0.40 & 1.90 \\
\hline \multirow{2}{*}{ Lip2 } & Octadecyl & 13.89 & 1.80 & 0.80 & 2.60 \\
& CNBr-activated & 2.84 & 1.00 & 0.60 & 1.60 \\
\hline
\end{tabular}


In general, F. verticillioides lipases proved to be very selective and released EPA better than DHA. Similar results were obtained by Fernandez-Lorente et al. [14], where the release of DHA was lower than EPA. F. verticillioides lipases also showed 4-fold higher selectivity compared to EPA released from Rhizomucor miehei lipase immobilized on octyl support [7]. Pizarro et al. [8] after $48 \mathrm{~h}$ hydrolysis reached maximum conversion of EPA and DHA of $8.7 \%$ and $6.1 \%$ respectively.

\subsubsection{Hydrolysis of Racemic Mixtures}

In this application, Lip1 and Lip2 were used immobilized on octyl and octadecyl supports, respectively. Moreover, they were necessary to compare these results with CNBr-activated derivatives.

\section{2-O-butyryl-2-phenylacetic}

Lip2 showed better conversion rates in a shorter period of time, 10.3\%; while Lip1 reached half of this value. Both CNBr-activated derivatives required longer periods to achieve some conversion rate (Table 8).

Table 8. 2-O-butyryl-2-phenylacetic hydrolysis by Lip1 and Lip2.

\begin{tabular}{cccccccc}
\hline Lipase & Derivatives & Time $\mathbf{( h )}$ & Conversion $\mathbf{( \% )}$ & $\mathbf{S A} * \mathbf{( U / m g )}$ & Selectivity E & ee & Isomer \\
\hline \multirow{2}{*}{ Lip1 } & CNBr-activated & 240 & 1.7 & 0.25 & 1.0 & 21.2 & $\mathrm{~S}$ \\
& Octyl & 144 & 4.8 & 1.15 & 3.4 & 54.5 & $\mathrm{~S}$ \\
\hline \multirow{2}{*}{ Lip2 } & CNBr-activated & 336 & 2.0 & 0.28 & 1.3 & 13.6 & $\mathrm{~S}$ \\
& Octadecyl & 144 & 10.3 & 4.51 & 2.6 & 44.3 & $\mathrm{~S}$ \\
\hline \multicolumn{5}{c}{ *SA $=$ Specific Activity. }
\end{tabular}

The second analysis refers to selectivity (E) and enantiomeric excess (ee) coefficients evaluated by HPLC analysis using a chiral column. Lip1 presented the best $\mathrm{E}$ and ee results; however, both lipases indicated a high isomer S purity. This result corroborates with Fernandez-Lorente et al. [34] which reported the enzyme preparation of Aspergillus niger lipases, immobilized on DEAE-Sepharose, that showed different $\mathrm{E}$ values but preferred enantiomer $\mathrm{S}$. However, not all authors reported $\mathrm{S}$ as the preferred isomer, as the reported for Mucor miehei lipase that the conversion of the $\mathrm{R}$ isomer by octadecyl derivative, with a value of E equal to 5.0 and $e e$ around 51.0 [12].

HPBE Hydrolysis

HPBE hydrolysis presented excellent conversion rates by both lipases in a shorter time than 2-O-butyryl-2-phenylacetic acid, probably indicating preference by this substrate (Table 9). Octyl derivative obtained the best conversion rate reaction in just $1.5 \mathrm{~h}$ and therefore its specific activity increased by about 400 times when compared with other derivatives (after 96 h). Higher specificity, around 3.5, was reached by both lipases. However, excellent $\mathrm{E}$ and $e e$ values have been reported by Fernandez-Lorente et al. [35], in which Pseudomonas fluorescens lipase reached 86 and 92.5, respectively.

Table 9. HPBE hydrolysis by Lip1 and Lip2.

\begin{tabular}{cccccccc}
\hline Lipase & Derivatives & Time (h) & Conversion $\mathbf{( \% )}$ & $\mathbf{S A} * \mathbf{( U / m g})$ & Selectivity E & ee & Isomer \\
\hline \multirow{2}{*}{ Lip1 } & CNBr-activated & 96 & 18 & 6.51 & 2.1 & 35.7 & $\mathrm{~S}$ \\
& Octyl & 1.5 & 6.9 & 159.7 & 3.7 & 57.6 & $\mathrm{~S}$ \\
\hline \multirow{2}{*}{ Lip2 } & CNBr-activated & 96 & 10.8 & 5.4 & 1.4 & 17.8 & $\mathrm{R}$ \\
& Octadecyl & 96 & 10.8 & 7.13 & 3.6 & 56.2 & $\mathrm{~S}$ \\
\hline
\end{tabular}

*SA $=$ Specific Activity. 


\section{Materials and Methods}

\subsection{Microorganism and Culture Maintenance}

Fusarium verticillioides stock culture was maintained on oatmeal agar medium, at $4{ }^{\circ} \mathrm{C}$ and in silica gel at $-20^{\circ} \mathrm{C}$.

\subsection{Lipase Production}

Lipase production was carried out in $125 \mathrm{~mL}$ Erlenmeyers flasks under $100 \mathrm{rpm}$, at $30{ }^{\circ} \mathrm{C}$, for 4 days. The liquid culture medium was composed by $0.2 \%$ peptone, $0.05 \% \mathrm{MgSO}_{4}, 0.1 \%$ monobasic sodium phosphate and $1 \%$ sunflower oil. The filtrate named FVL (Fusarium verticillioides lipase) was collected by vacuum filtration and stored at $4{ }^{\circ} \mathrm{C}$ [36].

\subsection{Measurement of Lipase Activity}

\subsection{1. $p$-Nitrophenyl Butyrate ( $p$ NPB)}

Lipolytic activity was measured by the increase in absorbance at $348 \mathrm{~nm}$ produced by the release of $p$ NPB hydrolysis, using a spectrophotometer equipped with a thermostatized chamber and continuous magnetic stirring, which kept the immobilized enzyme homogenously suspended. Standard assay conditions were $50 \mu \mathrm{L}$ of enzymatic sample (or suspension), $2.5 \mathrm{~mL}$ of $25 \mathrm{mM}$ sodium phosphate buffer, pH 7.0 containing $20 \mu \mathrm{L}$ of $50 \mathrm{mM}$ p-nitrophenylbutyrate diluted in pure acetonitrile. The mixture was incubated at $25{ }^{\circ} \mathrm{C}$ for different periods. One unit (U) of enzyme activity was defined as that catalyzing the conversion of $1 \mu \mathrm{mol}$ of substrate (or the formation of $1 \mu \mathrm{mol}$ of product) in $1 \mathrm{~min}$ in the assay conditions.

\subsection{2. $p$-Nitrophenyl Palmitate ( $p$ NPP)}

Lipase activities were determined using $p$ NPP according to Pencreach and Baratti (1996) [37]. The reaction was carried out using Mcllvaine buffer ( $\mathrm{pH} 5.5$ or 6.0), at $40{ }^{\circ} \mathrm{C}$ [38]. One unit (U) of enzyme activity was defined as that catalyzing the conversion of $1 \mu \mathrm{mol}$ of substrate (or the formation of $1 \mu$ mol of product) in $1 \mathrm{~min}$ in the assay conditions.

\subsection{Lipase Hydrophobic Immobilization}

The adsorption of enzyme was analyzed in hydrophobic supports: Butyl Sepharose, Hexyl Toyopearl, Phenyl Toyopearl, Octyl Sepharose and Octadecyl Sepabeads. One gram of each support was added to $5 \mathrm{~mL}$ of $10 \mathrm{mM}$ sodium phosphate buffer, at $\mathrm{pH} 7$ and to $5 \mathrm{~mL}$ of the crude extract. All suspensions were incubated at $25^{\circ} \mathrm{C}$ with constant stirring. Periodically, suspension and supernatant activities were assayed by using the $p$ NPB assay. Once adsorbed, the immobilized preparations (derivatives) were thoroughly washed with distilled water, filtered and stored at $4{ }^{\circ} \mathrm{C}$. A blank suspension was prepared by adding $1 \mathrm{~g}$ of Sepharose 4 BCL. The initial protein offered was specified by Bradford's method [39].

\subsection{Hydrophobic Derivatives Thermal Stability}

In order to determine the thermal stability, the derivatives were incubated in $25 \mathrm{mM}$ sodium phosphate buffer ( $\mathrm{pH} 7.0)$ at different temperatures $\left(40{ }^{\circ} \mathrm{C}\right.$ to $\left.70{ }^{\circ} \mathrm{C}\right)$. Samples were withdrawn at different times using a pipette with a cut-tip and under strong stirring aiming a homogeneous biocatalyst suspension. The activity, measured immediately after withdrawn, was determined by the $p$ NPB assay. The experiments were carried out in triplicates. 


\subsection{Cascade Purification}

It was performed a sequential immobilization with adsorption of $F$. verticillioides crude extract in octyl followed by octadecyl supports at a low ionic strength. Previously, the crude enzymatic extract was diluted in $10 \mathrm{mM}$ sodium phosphate buffer at $\mathrm{pH} 7(1: 2 \mathrm{v} / \mathrm{v})$ and sequentially, $1 \mathrm{~g}$ of octyl support was added. After adsorption, the supernatant was added to $1 \mathrm{~g}$ of octadecyl support until complete adsorption. After immobilization, both derivatives were thoroughly washed with distilled water and with increasing concentrations of Triton X-100 until the complete desorption.

The analysis of the adsorbed lipases on supports was performed using SDS-PAGE. Aiming to verify the lipases purity in both supports, $0.1 \mathrm{~g}$ of each derivative was suspended in $0.5 \mathrm{~mL}$ of rupture buffer, containing bromophenol, $10 \%(v / v)$ mercaptoethanol, $40 \%$ glycerol and $4 \%(w / v)$ SDS. After boiling for $5 \mathrm{~min}$, the supernatant of the derivatives was quickly withdrawn and analyzed by SDS-PAGE. The gel was stained using silver nitrate or Coomassie method. Molecular weight markers were from a Pharmacia LMW kit (14,400-94,000 Da).

After purification, the enzyme recuperation, specific activity (SA) and the purification factor (PF) were calculated. The purification factor shows how much the specific activity increased compared to the crude preparation $(\mathrm{PF}=\mathrm{SA} / \mathrm{SA}$ crude extract $)$.

\subsection{Enzyme Desorption}

In order to analyze the mechanism of lipase desorption, $250 \mathrm{mg}$ of derivatives were diluted to $2.5 \mathrm{~mL}$ of $25 \mathrm{mM}$ sodium phosphate buffer at $\mathrm{pH} 7$ and were sequentially washed with different concentrations of Triton X-100.

\subsection{Immobilization of the Lipase on CNBr-Activated Support}

Immobilization of both desorbed lipases on $\mathrm{CNBr}$-activated support was prepared by Pharmacia protocol, at $\mathrm{pH}$ 7. The immobilization occurred through the lipase amino terminal group [35]. One gram of CNBr-activated support was added to a solution of $10 \mathrm{~mL}$ of purified lipase in $25 \mathrm{mM}$ sodium phosphate buffer, at pH 7.0. After $30 \mathrm{~min}$, the enzyme immobilization was ended by blocking the amine reactive groups with $1 \mathrm{M}$ ethanolamine, at $\mathrm{pH} 8$. After $2 \mathrm{~h}$, the immobilized preparation was washed with abundant distilled water.

\subsection{Biochemical Characterization of Lipases}

\subsubsection{Temperature and $\mathrm{pH}$ Influence}

The optima of temperature and $\mathrm{pH}$ were determined to each lipase. In order to determine the thermal stability, both derivatives were incubated in $25 \mathrm{mM}$ sodium phosphate, $\mathrm{pH} 7.0$ at different temperatures. The residual activity was measured after incubation. As the same, the $\mathrm{pH}$ stability was carried out in a range of $\mathrm{pH} 3.0-10.0$, the enzymes were pre-incubated in citrate phosphate buffer (range 3.0-7.0), sodium phosphate $0.1 \mathrm{~mol} \cdot \mathrm{L}^{-1}$ ( $\mathrm{pH} 7.0$ ), Tris- $\mathrm{HCl}$ (range, 8.0-9.0) and glycine (pH 10.0) at $25{ }^{\circ} \mathrm{C}$, for $24 \mathrm{~h}$. Samples were withdrawn at different times using a pipette with a cut-tip and under strong stirring aiming a homogeneous biocatalyst suspension. The activity, measured immediately after withdrawn, was determined by the $p \mathrm{NPB}$ assay, as described above. The experiments were carried out in triplicates.

\subsubsection{Effect of Metallic Ions}

In order to determine the effect of metallic ions on lipases activity, assays were performed at the final concentrations of 5 and $10 \mathrm{mM}$ of $\mathrm{Zn}\left(\mathrm{NO}_{3}\right)_{2} \cdot 6 \mathrm{H}_{2} \mathrm{O} ; \mathrm{NaCl}, \mathrm{NH}_{4} \mathrm{Cl}, \mathrm{BaCl}_{2}, \mathrm{MnCl}_{2} \cdot 4 \mathrm{H}_{2} \mathrm{O}$, $\mathrm{CoCl}_{2} \cdot 6 \mathrm{H}_{2} \mathrm{O}, \mathrm{MgCl}_{2}, \mathrm{AlCl}_{3} \cdot 6 \mathrm{H}_{2} \mathrm{O}, \mathrm{CuSO}_{4} \cdot 5 \mathrm{H}_{2} \mathrm{O}, \mathrm{CaCl}_{2}, \mathrm{~Pb}\left(\mathrm{C}_{2} \mathrm{H}_{3} \mathrm{O}_{2}\right) \cdot 3 \mathrm{H}_{2} \mathrm{O}, \mathrm{NaBr}, \mathrm{KCl}$ and EDTA. The activity in the absence of these components was defined as the control. 


\subsubsection{Isoelectric Point and Kinetic Parameters}

Isoelectric focusing was carried out according to O'Farrel et al. [40], using Pharmalyte Ampholyte ( $\mathrm{pH}$ range 3.0-10.0). The apparent kinetic parameters $\mathrm{K}_{\mathrm{M}}, \mathrm{V}_{\max }$ and kcat of the FVLs were determined and calculated by SigrafW software [41,42].

\subsection{Hydrolysis of Sardine Oil}

The sardine oil composition has been previously reported by Fernandez-Lorente et al. [2,6] and the main fat acids present are eicosapentaenoic acid (EPA, 18.6\%), docosahexaenoic acid (DHA, 12.7\%), palmitic acid (16.1\%) and oleic acid (11.7\%). The release of EPA and DHA was analyzed. The hydrolysis was performed in an organic-aqueous system, in which $4.5 \mathrm{~mL}$ of cyclohexane, $5 \mathrm{~mL}$ of Tris- $\mathrm{HCl}$ buffer $(0.01 \mathrm{M}) \mathrm{pH} 6.0,0.5 \mathrm{~mL}$ of sardine oil and $0.5 \mathrm{U} / \mathrm{g}$ of each lipase derivative were incubated at $25{ }^{\circ} \mathrm{C}$ and stirred at $150 \mathrm{rpm}$. The control samples did not have derivatives. Aliquots were withdrawn after 7 and 14 days. The concentration of free fatty acids was determined by the HPLC-UV method. The chromatograms of the aliquots from the organic phase obtained from UV-HPLC were compared to the corresponding calibration curves to facilitate the calculation of the rates of hydrolysis (EPA + DHA) and the EPA/DHA ratios. Aliquots of $0.1 \mathrm{~mL}$ from organic phase were withdrawn and dissolved in $0.4 \mathrm{~mL}$ of acetonitrile. The organic phase was easily separated from the aqueous phase after stopping stirring. The unsaturated fatty acids produced were analyzed by RP-HPLC [Spectra Physic SP 100 coupled with an UV detector Spectra Physic SP 8450 (Spectra Physics, Santa Clara, CA, USA)] using a Kromasil C8 $(5 \mu \mathrm{m}, 15 \mathrm{~cm} \times 0.4 \mathrm{~cm})$ column. Products were eluted at a flow rate of $1.0 \mathrm{~mL} / \mathrm{min}$ using acetonitrile-milli-Q water- acetic acid, $\mathrm{pH} 3.0(70: 30: 1, v / v)$ and UV detection performed at $215 \mathrm{~nm}$. The retention times for the unsaturated fatty acids were $9.4 \mathrm{~min}$ (EPA) and $13.5 \mathrm{~min}$ (DHA). These produced fat acids were compared to their corresponding pure commercial standards.

\subsection{Ethanolysis of Sardine Oil}

The enzymatic ethanolysis was investigated to octadecyl Sepabeads derivatives for both lipases (Lip1 and Lip2), at $0.5 \mathrm{U} / \mathrm{g}$. The procedure was performed in an organic solvent system containing $0.5 \mathrm{~g}$ of molecular sieves to guarantee total water absorption. First, $1.77 \mathrm{~mL}$ of sardine oil, $0.9 \mathrm{~mL}$ of ethanol and $0.5 \mathrm{U} / \mathrm{g}$ of lipase preparation were intensely mixed and incubated at $25^{\circ} \mathrm{C}, 150 \mathrm{rpm}$. The control samples did not have derivatives. After 7 and 14 days, aliquots of $8 \mu \mathrm{L}$ were diluted in $992 \mu \mathrm{L}$ of acetonitrile and the concentration of free fatty acids esters was determined by RP-HPLC [Spectra Physic SP 100 coupled with an UV detector Spectra Physic SP 8450 (Spectra Physics, Santa Clara, CA. USA)] using an Ultrabase C18 $(5 \mu \mathrm{m}, 150 \times 4.6 \mathrm{~mm})$ column. The flow rate elution was $1.0 \mathrm{~mL} / \mathrm{min}$ with acetonitrile-milli-Q water- acetic acid, $\mathrm{pH} 3.0(80: 20: 0.1, v / v)$ and UV detection performed at $215 \mathrm{~nm}$. The retention times were $20 \mathrm{~min}$ (EPA) and $26 \mathrm{~min}$ (DHA). The area of EPA and DHA chromatograms were compared to their corresponding pure commercial standards.

\subsection{Hydrolysis of Racemic Mixtures}

The different immobilized derivatives were assayed by adding $0.3 \mathrm{~g}$ of wet immobilized preparations $(0.3-0.6 \mathrm{U} / \mathrm{g})$ to the $(R, S)$-2-Hydroxy-4-phenylbutanoic acid ethyl ester (HPBE) $(2 \mathrm{mM}$, $20 \mathrm{~mL}$ ) or $(R, S)$-2-O-butyryl-2-phenylacetic acid solutions $(10 \mathrm{mM}, 10 \mathrm{~mL})$, prepared in $25 \mathrm{mM}$ sodium phosphate buffer, $\mathrm{pH} 5(2.5 \mathrm{~mL})$, at $25^{\circ} \mathrm{C}$, under mechanical stirring. The control experiments were performed using the support without enzymes. The mobile phases were: (1) for mandelic acid an isocratic mixture of acetonitrile (35\%) and $10 \mathrm{mM}$ ammonium phosphate buffer (65\%) at $\mathrm{pH} 3.0$; (2) for HPBE an isocratic mixture of acetonitrile $(40 \%)$ and $10 \mathrm{mM}$ ammonium phosphate buffer $(60 \%)$ at $\mathrm{pH}$ 2.9. The detection was at $220 \mathrm{~nm}$ and $1.0 \mathrm{~mL} / \mathrm{min}$ flow rate.

The optical purity of the hydrolyzed product as enantiomeric excess of the chiral product (ee), the extent of conversion of the racemic mixture and the enantiomeric ratio or enantioselectivity $(E)$ were important parameters to be analyzed. At different conversion degrees, the enantiomeric excesses 
of the released acid were analyzed by HPLC using a Chiracel OD-R column [43]. The mobile phase was an isocratic mixture of acetonitrile $/ \mathrm{NaClO}_{4} / \mathrm{HClO}_{4} 0.5 \mathrm{M}(5: 95), \mathrm{pH} 2.3$. The analyzes were performed at a flow rate of $0.5 \mathrm{~mL} / \mathrm{min}$ and at $225 \mathrm{~nm}$. Enantioselectivity value and the conversion degree were calculated $[10,12]$.

\subsection{Transesterification Reaction}

The pure Lip1 was desorbed from octyl support and adsorbed on octadecyl Sepabeads. The enzymatic transesterification was carried out in a non-aqueous medium, with a molar ratio of 1:9 (oil:ethanol), $20 \mathrm{~mL}$, including $6 \% \mathrm{n}$-hexane and lipases derivatives. Ethanol was added in two steps to prevent any interference in the enzyme activity. All experiments were performed at $40{ }^{\circ} \mathrm{C}$, $150 \mathrm{rpm}$ for $24 \mathrm{~h}$.

\subsection{Thin Layer Chromatography Analysis (TLC)}

The preliminary transesterification results were obtained by analyzing the ester released by TLC. The reaction carried out on silica gel G-60 plates $\left(\operatorname{Merk}^{\circledR}\right)$. The migration solvent consisted in a mixture of hexane: ethyl acetate: acetic acid (90:10:1). Chromatograms were revealed in an iodine vapor atmosphere [44].

\subsection{Transesterification Assay by Gas Chromatography (CG-MS)}

The product of enzymatic transesterification samples was diluted in $1 \%$ methanol and the samples were analyzed using an HP gas chromatograph (model GC-2012 5890) with a BP column (1.30 m length and $0.25 \mathrm{~mm}$ internal diameter). The mobile phase consisted of helium gas flow of $1.47 \mathrm{~mL} /$ minute. The analysis was accomplished by using a temperature ramp from 80 to $200{ }^{\circ} \mathrm{C}$ with an injector at temperature of $200^{\circ} \mathrm{C}$. The mass spectra of the main chromatographic peaks were monitored in a mass spectrometer model GCMS-QP 2010 Plus, which was coupled to the chromatograph. Standard curves were performed using ethyl oleate with 23 min of retention time. All esters produced between 23 and 26 min were considered as lipase product.

\section{Conclusions}

Cascade purification was a simple and rapid method to isolate and purify two lipases from the same crude extract with differences in hydrophobicity. The lipase adsorption, at low ionic strength, increased lipase activity and stability. The characterization and application demonstrated two different enzymes with distinct properties, mainly in their transesterification capacity. Moreover, the results indicated a slightly enantioselectivity improvement; the transesterification reactions showed excellent capacity of Lip2 to be used in biodiesel production and hydrolysis of sardine oil, releasing omega 3 , suggesting the enzyme applicability in industrial food processes. Improvements using genetic engineering are been studied.

Supplementary Materials: The following are available online at www.mdpi.com/2073-4344/8/2/84/s1, Figure S1: SDS-PAGE analysis. (A) pure Lip1 adsorbed on octyl Sepharose (B) pure Lip2 adsorbed on octadecyl Sepabeads. M: molecular marker; 1: crude extract before immobilization; 2: octyl supernatant; 3: octyl derivative; 4: octadecyl derivative.

Acknowledgments: This work was supported by grants from Fundação de Amparo à Pesquisa do Estado de São Paulo (FAPESP, n 2013/50892-5) and Conselho Nacional de Desenvolvimento Científico e Tecnológico (CNPq, $\left.\mathrm{n}^{\circ} 406838 / 2013-5\right)$. This project is also part of the National Institute of Science and Technology of the Bioethanol (FAPESP, $n^{\circ}$ 2010/52322-3). MLTMP is Research Fellow of CNPq. FDAF was recipient of a FAPESP fellowship ( $n^{\circ}$ 2012/14615-4). MGP and ACV are supported by CNPq. We thank Ricardo F. Alarcon, Mariana Cereia and Mauricio de Oliveira for the technical assistance.

Author Contributions: This work is part of the Ph.D of F.D.A.F. and she is the main author. M.G.P. and M.F. partially collaborated in the experiments with chemical synthesis reaction. A.C.V. assisted in enzyme reaction and the discussion of experiments. B.C.P. and G.F.-L. were responsible for designing the experiments. J.M.G. and M.L.T.M.P. contributed to the experimental design and the final manuscript. 
Conflicts of Interest: The authors declare no conflict of interest.

\section{References}

1. Cunha, A.G.; Fernandez-Lorente, G.; Gutarra, M.L.E.; Bevilaqua, J.V.; Almeida, R.V.; Paiva, L.M.C.; Fernandez-Lafuente, R.; Guisan, J.M.; Freire, D.M.G. Separation and immobilization of lipase from Penicillium simplicissimum by selective adsorption on hydrophobic supports. Appl. Biochem. Biotechnol. 2009, 156, 563-575. [CrossRef] [PubMed]

2. Fernandez-Lorente, G.; Pizarro, C.; Lopez-Vela, D.; Betancor, L.; Carrascosa, A.V.; Pessela, B.; Guisan, J.M. Hydrolysis of fish oil by lipases immobilized inside porous supports. J. Am. Oil Chem. Soc. 2011, 88, 819-826. [CrossRef]

3. Fernandez-Lorente, G.; Betancor, L.; Carrascosa, A.V.; Palomo, J.M.; Guisan, J.M. Modulation of the selectivity of immobilized lipases by chemical and physical modifications: Release of Omega-3 fatty acids from fish oil. J. Am. Oil Chem. Soc. 2012, 89, 97-102. [CrossRef]

4. Cabrera, Z.; Palomo, J.M. Enantioselective desymmetrization of prochiral diesters catalyzed by immobilized Rhizopus oryzae lipase. Tetrahedron Asymmetry 2011, 22, 2080-2084. [CrossRef]

5. Acosta, A.; Filice, M.; Fernandez-Lorente, G.; Palomo, J.M.; Guisan, J.M. Kinetically controlled synthesis of monoglyceryl esters from chiral and prochiral acids methyl esters catalyzed by immobilized Rhizomucor miehei lipase. Bioresour. Technol. 2011, 102, 507-512. [CrossRef] [PubMed]

6. Fernandez-Lorente, G.; Filice, M.; Lopez-Vela, D.; Pizarro, C.; Wilson, L.; Betancor, L.; Avila, Y.; Guisan, J.M. Cross-Linking of lipases adsorbed on hydrophobic supports: Highly selective hydrolysis of fish oil catalyzed by RML. J. Am. Oil Chem. Soc. 2011, 88, 801-807. [CrossRef]

7. Filice, M.; Marciello, M.; Betancor, L.; Carrascosa, A.V.; Guisan, J.M.; Fernandez-Lorente, G. Hydrolysis of fish oil by hyperactivated Rhizomucor miehei lipase immobilized by multipoint anion exchange. Biotechnol. Prog. 2011, 27, 961-968. [CrossRef] [PubMed]

8. Pizarro, C.; Branes, M.C.; Markovits, A.; Fernandez-Lorente, G.; Guisan, J.M.; Chamy, R.; Wilson, L. Influence of different immobilization techniques for Candida cylindracea lipase on its stability and fish oil hydrolysis. J. Mol. Catal. B Enzym. 2012, 78, 111-118. [CrossRef]

9. Rodrigues, R.C.; Bolivar, J.M.; Palau-Ors, A.; Volpato, G.; Ayub, M.A.Z.; Fernandez-Lafuente, R.; Guisan, J.M. Positive effects of the multipoint covalent immobilization in the reactivation of partially inactivated derivatives of lipase from Thermomyces lanuginosus. Enzym. Microb. Technol. 2009, 44, 386-393. [CrossRef]

10. Brabcova, J.; Demianova, Z.; Vondrasek, J.; Jagr, M.; Zarevucka, M.; Palomo, J.M. Highly selective purification of three lipases from Geotrichum candidum 4013 and their characterization and biotechnological applications. J. Mol. Catal. B Enzym. 2013, 98, 62-72. [CrossRef]

11. Palomo, J.M.; Fernandez-Lorente, G.; Mateo, C.; Ortiz, C.; Fernandez-Lafuente, R.; Guisan, J.M. Modulation of the enantioselectivity of lipases via controlled immobilization and medium engineering: Hydrolytic resolution of mandelic acid esters. Enzym. Microb. Technol. 2002, 31, 775-783. [CrossRef]

12. Palomo, J.M.; Munoz, G.; Fernandez-Lorente, G.; Mateo, C.; Fuentes, M.; Guisan, J.M.; Fernandez-Lafuente, R. Modulation of Mucor miehei lipase properties via directed immobilization on different hetero-functional epoxy resins-Hydrolytic resolution of $(R, S)$-2-butyroyl-2-phenylacetic acid. J. Mol. Catal. B Enzym. 2003, 21, 201-210. [CrossRef]

13. Velasco-Lozano, S.; Rodriguez-Gonzalez, J.A.; Mateos-Diaz, J.C.; Reyes-Duarte, D.; Favela-Torres, E. Catalytic profiles of lipolytic biocatalysts produced by filamentous fungi. Biocatal. Biotransform. 2012, 30, 459-468. [CrossRef]

14. Fernandez-Lorente, G.; Betancor, L.; Carrascosa, A.V.; Guisan, J.M. Release of Omega-3 fatty acids by the hydrolysis of fish oil catalyzed by lipases immobilized on hydrophobic supports. J. Am. Oil Chem. Soc. 2011, 88, 1173-1178. [CrossRef]

15. Jallouli, R.; Khrouf, F.; Fendri, A.; Mechichi, T.; Gargouri, Y.; Bezzine, S. Purification and biochemical characterization of a novel alkaline (phospho)lipase from a newly isolated Fusarium solani strain. Appl. Biochem. Biotechnol. 2012, 168, 2330-2343. [CrossRef] [PubMed]

16. Jallouli, R.; Fendri, A.; Mechichi, T.; Gargouri, Y.T.; Bezzine, S. Kinetic properties of a novel Fusarium solani (phospho)lipase: A monolayer study. Chirality 2013, 25, 35-38. [CrossRef] [PubMed] 
17. Tehreema, L. Process optimization for extracellular lipase production from Fusarium oxysporum (mbl21) through solid state fermentation technique. Clin. Biochem. 2011, 44, S243. [CrossRef]

18. Bastida, A.; Sabuquillo, P.; Armisen, P.; Fernandez-Lafuente, R.; Huguet, J.; Guisan, J.M. Single step purification, immobilization and hyperactivation of lipases via interfacial adsorption on strongly hydrophobic supports. Biotechnol. Bioeng. 1998, 58, 486-493. [CrossRef]

19. Palomo, J.M.; Munoz, G.; Fernandez-Lorente, G.; Mateo, C.; Fernandez-Lafuente, R.; Guisan, J.M. Interfacial adsorption of lipases on very hydrophobic support (octadecyl-Sepabeads): Immobilization, hyperactivation and stabilization of the open form of lipases. J. Mol. Catal. B Enzym. 2002, 19, 279-286. [CrossRef]

20. Pereira, M.G.; Facchini, F.D.A.; Polizeli, A.M.; Vici, A.C.; Guisan, J.M.; Jorge, J.A.; Pessela, B.C.; Fernandez-Lorente, G.; Polizeli, M.L.T.M. Stabilization of the lipase of Hypocrea pseudokoningii by multipoint covalent immobilization after chemical modification and application of the biocatalyst in oil hydrolysis. J. Mol. Catal. B Enzym. 2015, 121, 82-89. [CrossRef]

21. Fernandez-Lorente, G.; Cabrera, Z.; Godoy, C.; Fernandez-Lafuente, R.; Palomo, J.M.; Guisan, J.M. Interfacially activated lipases against hydrophobic supports: Effect of the support nature on the biocatalytic properties. Process Biochem. 2008, 43, 1061-1067. [CrossRef]

22. Adan Gokbulut, A.; Arslanoglu, A. Purification and biochemical characterization of an extracellular lipase from psychrotolerant Pseudomonas fluorescens KE38. Turk. J. Biol. 2013, 37, 538-546. [CrossRef]

23. Pereira, M.G.; Vici, A.C.; Facchini, F.D.A.; Tristão, A.P.; Cursino-Santos, J.R.; Sanches, P.R.; Jorge, J.A.; Polizeli, M.L.T.M. Screening of filamentous fungi for lipase production: Hypocrea pseudokoningii a new producer with a high biotechnological potential. Biocatal. Biotransform. 2014, 32, 74-83. [CrossRef]

24. Mhetras, N.C.; Bastawde, K.B.; Gokhale, D.V. Purification and characterization of acidic lipase from Aspergillus niger NCIM 1207. Bioresour. Technol. 2009, 100, 1486-1490. [CrossRef] [PubMed]

25. Polizelli, P.P.; Antonio Facchini, F.D.; Cabral, H.; Bonilla-Rodriguez, G.O. A new lipase isolated from oleaginous seeds from Pachira aquatica (Bombacaceae). Appl. Biochem. Biotechnol. 2008, 150, $233-242$. [CrossRef] [PubMed]

26. Jermsuntiea, W.; Aki, T.; Toyoura, R.; Iwashita, K.; Kawamoto, S.; Ono, K. Purification and characterization of intracellular lipase from the polyunsaturated fatty acid-producing fungus Mortierella alliacea. New Biotechnol. 2011, 28, 158-164. [CrossRef] [PubMed]

27. Shangguan, J.J.; Liu, Y.Q.; Wang, F.J.; Zhao, J.; Fan, L.Q.; Li, S.X.; Xu, J.H. Expression and Characterization of a novel lipase from Aspergillus fumigatus with high specific activity. Appl. Biochem. Biotechnol. 2011, 165, 949-962. [CrossRef] [PubMed]

28. Bharti, M.K.; Khokhar, D.; Pandey, A.K.; Gaur, A.K. Purification and characterization of lipase from Aspergillus japonicus: A potent enzyme for biodiesel production. Natl. Acad. Sci. Lett. 2013, 36, 151-156. [CrossRef]

29. Vici, A.C.; Cruz, A.F.; Facchini, F.D.A.; Carvalho, C.C.; Pereira, M.G.; Fonseca-Maldonado, R.; Ward, R.J.; Pessela, B.C.; Fernandez-Lorente, G.; Torres, F.A.G.; et al. Beauveria bassiana Lipase A expressed in Komagataella (Pichia) pastoris with potential for biodiesel catalysis. Front. Microbiol. 2015, 6. [CrossRef] [PubMed]

30. Abdulla, R.; Ravindra, P. Immobilized Burkholderia cepacia lipase for biodiesel production from crude Jatropha curcas L. oil. Biomass Bioenergy 2013, 56, 8-13. [CrossRef]

31. Salis, A.; Pinna, M.; Monduzzi, M.; Solinas, V. Biodiesel production from triolein and short chain alcohols through biocatalysis. J. Biotechnol. 2005, 119, 291-299. [CrossRef] [PubMed]

32. Shao, P.; Meng, X.H.; He, J.Z.; Sun, P.L. Analysis of immobilized Candida rugosa lipase catalyzed preparation of biodiesel from rapeseed soapstock. Food Bioprod. Process. 2008, 86, 283-289. [CrossRef]

33. Moreno-Perez, S.; Guisan, J.M.; Fernandez-Lorente, G. Selective ethanolysis of fish oil catalyzed by immobilized lipases. J. Am. Oil Chem. Soc. 2014, 91, 63-69. [CrossRef]

34. Fernandez-Lorente, G.; Ortiz, C.; Segura, R.L.; Fernandez-Lafuente, R.; Guisan, J.M.; Palomo, J.M. Purification of different lipases from Aspergillus niger by using a highly selective adsorption on hydrophobic supports. Biotechnol. Bioeng. 2005, 92, 773-779. [CrossRef] [PubMed]

35. Fernandez-Lorente, G.; Palomo, J.M.; Cabrera, Z.; Fernandez-Lafuente, R.; Guisan, J.M. Improved catalytic properties of immobilized lipases by the presence of very low concentrations of detergents in the reaction medium. Biotechnol. Bioeng. 2007, 97, 242-250. [CrossRef] [PubMed] 
36. Facchini, F.D.A.; Vici, A.C.; Pereira, M.G.; Jorge, J.A.; Polizeli, M.L.T.M. Enhanced lipase production of Fusarium verticillioides by using response surface methodology and wastewater pretreatment application. J. Biochem. Technol. 2015, 6, 996-1002.

37. Pencreach, G.; Baratti, J.C. Hydrolysis of p-nitrophenyl palmitate in n-heptane by the Pseudomonas cepacia lipase: A simple test for the determination of lipase activity in organic media. Enzym. Microb. Technol. 1996, 18, 417-422. [CrossRef]

38. Mcllvaine, T.C. A buffer solution for colorimetric comparison. J. Biolog. Chem. 1921, 49, 183-186.

39. Bradford, M.M. Rapid and sensitive method for quantitation of microgram quantities of protein utilizing principle of protein-dye binding. Anal. Biochem. 1976, 72, 248-254. [CrossRef]

40. O'Farrel, P.Z.; Goodman, H.M.; O'Farrel, P.H. High resolution two dimensional electrophoresis of basic as acidic proteins. Cell 1977, 12, 1133-1142. [CrossRef]

41. Leone, F.A.; Degreve, L.; Baranauskas, J.A. SIGRAF: A versatile computer program for fitting enzyme kinetics data. Biochemistry 1992, 20, 94-96. [CrossRef]

42. Leone, F.A.; Baranauskas, J.A.; Furriel, R.P.M.; Borin, I.A. SIGRAFW: An easy-to-use program for fitting enzyme kinetic data. Biochem. Mol. Biol. Educ. 2005, 33, 399-403. [CrossRef] [PubMed]

43. Fernandez-Lorente, G.; Terreni, M.; Mateo, C.; Bastida, A.; Fernandez-Lafuente, R.; Dalmases, P.; Huguet, J.; Guisan, J.M. Modulation of lipase properties in macro-aqueous systems by controlled enzyme immobilization: Enantioselective hydrolysis of a chiral ester by immobilized Pseudomonas lipase. Enzym. Microb. Technol. 2001, 28, 389-396. [CrossRef]

44. Shah, S.; Sharma, S.; Gupta, M.N. Biodiesel preparation by lipase-catalyzed transesterification of Jatropha oil. Energy Fuels 2004, 18, 154-159. [CrossRef]

(C) 2018 by the authors. Licensee MDPI, Basel, Switzerland. This article is an open access article distributed under the terms and conditions of the Creative Commons Attribution (CC BY) license (http:/ / creativecommons.org/licenses/by/4.0/). 